\title{
Ways to form a teacher's professionalism
}

\author{
Irina Burlakova ${ }^{1 *}$, Svetlana Bogatyreva $^{1}$, and Oksana Pavlova $^{2}$ \\ ${ }^{1}$ K.G. Razumovsky Moscow State University of Technologies and Management (the First Cossack \\ University), 109004, 73 Zemlyanoy Val str., Moscow, Russia \\ ${ }^{2}$ Kaluga state University, 248023, 26 Stepan Razin str., Kaluga, Russia
}

\begin{abstract}
The role of the teacher at the present stage is transformed into a high mission of creating a professional personality, which is intended to instill in students readiness to acquire knowledge and improve professional skills throughout their lives. According to the authors, the goal of pedagogical education is continuous general and professional development of a university teacher to achieve high results in the practical professional activity. In general, the professional competence of a University teacher is a synthesis of professionalism (scientific, special, methodological, psychological and pedagogical training), creativity (creativity of relationships, the optimal use of tools, techniques, teaching methods) and art (acting and public speaking). And today it becomes obvious that it is impossible to "add up" a competent professional from a simple sum of knowledge, because in addition, a University teacher should have a great sense of moral responsibility when teaching the modern generation of students.
\end{abstract}

\section{Introduction}

The intensity of changes that have occurred recently in many areas of human life has determined the significance of the requirements for the quality of modern education. The quality of education is improved by modernizing its procedural, organizational, and content aspects, and by optimizing the professional activities of teachers. In this regard, the professional competence of a University teacher must meet modern requirements that contribute to the development of the higher education system in the whole.

The solution of this task is possible on the basis of complex and system approaches. With the variety of forms, means training and technologies that a University teacher uses in the course of classroom work, it remains important to recognize the fact that students of universities are not sufficiently prepared to work after getting a diploma [1].

\footnotetext{
** Corresponding author: iiburlakova@mail.ru
} 


\section{Methods}

The methods of our research are: content analysis of literature on the problem, included supervision of teachers of the first 5 years of work at the University, questionnaires and analysis of the received material, modeling of situations.

\section{Results}

The theoretical and methodological basis of the study was the fundamental works: on the theory and methodology of teaching (B. S. Gershunsky, N.D. Galskova, V. Y. Laudis Yu. V. Proshunina, E.I. Passov, etc.).

The analysis of the concept «profession» leads to the conclusion that the profession fixes: the content characteristics of professional activity of an employee; the specialty that a person develops; the area of application of physical and spiritual forces of a person. Also, it is assumed the presence of a qualitative characteristic of mastering this specialty. At the same time, this quality is associated with the promotion of a person to the top of professionalism, and with the improvement of the professional's personality. In addition, the very fact that there are professionals with different levels of professionalism entails the need to recognize a certain professional evolution of a person. As a result, a person can change the quality indicators of professional life. The goal of the University is to teach students to learn, thereby preparing them for self-education throughout their life in order to improve their professional knowledge and skills on the way to professionalism [2].

Professional competence of a University teacher is defined as a combination of professional and personal qualities. Professionally competent can be called a teacher who carries out pedagogical activities and pedagogical communication at a sufficiently high level and achieves consistently high results in teaching and educating students. The development of professional competence is the development of the creative personality of the teacher, the formation of receptivity to pedagogical innovations, the ability to adapt in a changing educational environment [2].

It is known from the practice of higher education that some teachers develop the following stereotypes [3]:

- the desire to build the educational process according to the scheme «presentation perception - reproduction - consolidation - practice»;

- orientation to the content;

- hypertrophy of the control function in training;

- the prevalence of their own activity in practical classes, the desire to tell, explain, repeat everything again and again;

- communication assessment of the individuality of a student;

- the desire for excessive detail, simplification of material;

- organization of the students' behaviour to the detriment of the organisation of their activities, which usually leads to conflicts with students.

There are several types of relationships between teachers and students:

- consistently positive. Teachers of this group are distinguished by their pedagogical orientation, breadth of knowledge, erudition, deep mastery of the subject, flexibility of thinking, and the need for informal communication with students;

- passive-positive. It is manifested in an emotionally positive orientation when communicating with students. Such teachers often help them;

- negative. Such teachers have a tendency to constant edification; the formalization of relations with students is violent, and the attitude to pedagogy is negative. Students are not always satisfied with the state of pedagogical communication. They relate the effectiveness of the learning process directly to the personality of the teacher. 
Students subject everything to critical analysis in the teacher: appearance, characterological features, erudition, form of organization and conduct of classes, educational influences, actions.

\section{Discussion}

The role of the teacher is traditionally determined by the function of transferring and activating knowledge and professional skills. Now it is transformed into a high mission of forming a professional personality, which is designed to instil in students a readiness to acquire knowledge and improve professional skills throughout their lives. To achieve high results in the practical professional activity of a University teacher, the goal of pedagogical education is indicated - continuous general and professional development of a higher school teacher with high moral qualities, active participation in public life, with humanism, spirituality, morality, critical attitude to their actions, readiness to create new values and make creative decisions [4].

Modern didactics of higher education defines new theories and methods of teaching, which are based on the following approaches: personality-oriented, competence-based, system-activity, activity-based. These approaches are applied in accordance with the Standard of education, which assumes not only the traditional content of the minimum requirements, but also the set of professional skills [5].

University teaching is an art and science. Art, because every activity is unique. Its emotional colour and means depend on a number of factors, many of which are difficult to predict in advance. In this sense, teaching is like the work of an artist or writer, which requires a deep knowledge of life, the human soul, the ability to see, understand and empathize. But at the same time, it is also a science based on objective laws that fix essential connections and relationships in the process of perception and assimilation of educational material. These laws act as if in the role of load-bearing structures that ensure the process of formation of a specialist's personality [6].

The object of pedagogical work is also very specific - a person with individual qualities, who is under the influence of many factors and people who transform him. Many of these factors act spontaneously, in multiple ways, and in different directions. The teacher creates not alone, but together with other people [7].

In general, the qualities of a University teacher can be grouped into several blocks:

- social activity, sense of duty;

- professional qualities: deep knowledge of the specialty, higher school didactics, pedagogical psychology, teaching methods;

- personal qualities of a teacher: the ability to set pedagogical goals and determine the tasks of educational activities, develop students' interest in science, subject, conduct training with high final results, effectively carry out educational work; knowledge of student psychology, the ability to control the work of students, interact with them;

- moral qualities: honesty, benevolence, high demands on yourself and students, fairness in relations with students and colleagues, a sense of responsibility.

Students appreciate such qualities in the teacher as: kindness, unobtrusive influence, passion, humanity, sense of tact, ability to understand, sociability, sense of humour. As practice shows, human qualities are no less important than professional ones for young people. First, they look at what kind of person he/she is, and then they pay attention to how he/she teaches. Students learn better from popular teachers and rarely miss classes. Popularity is synonymous with respect and trust [8].

The moral image of a teacher should be characterized by honour and dignity - the desire to preserve their name, authority, reputation, respect for colleagues and students. 
The pedagogical activity of a University teacher involves educational and methodological work, organizing extracurricular activities, supervising study groups, as well as fulfilling administrative requirements, such as technical support for Internet resources, maintaining electronic documentation, and conducting practical classes in an inclusive environment [9].

In the context of the new Standard, the content of professional competencies is expanded [10]:

- communicative competence (practical knowledge of communication techniques that allows for effective interaction in the «teacher-student system»);

- research and innovation competence (the ability to plan, organize, conduct and analyse a pedagogical experiment);

- competence to transmit their own positive experience to the pedagogical community in articles, speeches, participation in competitions;

- acmeological competence (the ability to constantly improve professional skills, the ability to choose the necessary areas and forms of activity for professional growth); etc.

The development of professional competence is the development of the creative personality of the teacher, the formation of receptivity to pedagogical innovations. The changes in the modern system of higher education make it necessary to improve the teacher's skills as the main goal of modern education is to meet the current and future needs of the individual, to prepare a citizen capable of social adaptation in society [11]. A freethinking teacher who predicts the results of his activities and models the educational process is the key to achieving the goals. That is why the demand for a qualified, creative, competitive individual University teacher has increased nowadays [12].

It is possible to determine the main ways to develop the professional competence of a University teacher: work in methodological commissions and creative teams; research and experimental activities; innovations, development of new pedagogical technologies; various forms of pedagogical support; active participation in professional competitions, master classes, forums and festivals; generalization of their own pedagogical experience; publication activity [13].

Improvement of professional competence implies the need to motivate and create favourable conditions for professional growth. It is necessary to create the conditions in which the teacher independently realizes the need to improve the level of their own professional qualities [14]. The analysis of their own teaching experience activates professional self-development of the teacher. In result research skills are developed. Then they integrate into teaching activities. Each teacher should be involved in the process of managing the development of the University, which contributes to the development of its professionalism too.

The development of professional competence of a University teacher is a dynamic process of mastering and modernizing professional experience, leading to the development of individual professional qualities, the accumulation of professional experience [15].

It is possible to distinguish the stages of formation of professional competence of a University teacher: self-analysis; planning of self-development (goals, tasks, solutions); self-manifestation, self-correction [16].

The main indicators of professional competence of a teacher (on the example of a foreign language teacher) include the ability to develop students ' communicative and interpersonal communication. The components of professional competence are linguistic, thematic, socio-cultural, educational and cognitive competencies [17].

Communicative competence involves not only the formation of such personal qualities as sociability, openness in interaction with other people, but also the development of students ' practical skills to manage their educational activities. In teaching activities, it is 
necessary to create conditions for students to show independence and creativity in solving communication problems allowing students to see their growth and their achievements [18].

Reflexive competence is [19]:

- a characteristic of a student's actual learning capabilities;

- the ability of a teacher to determine the type of practical training in accordance with the tasks and content of the educational material, to justify the choice of its content and the optimality of the chosen methods and techniques of training; i.e., to correlate the theory of learning with practice, the ability to project the data obtained on the individual-specific features of the student's personality and a specific learning environment.

One of the tools for self-improvement of a foreign language teacher's competence is self-analysis of the lesson. It provides an opportunity to form and develop creative consciousness, which is manifested in the ability to formulate and set goals for their activities and students ' activities. For successful work in the classroom, a competent foreign language teacher must adhere to the requirements for the content and methodology of practical classes [20].

Requirements for the content of practical training in a foreign language: scientific; developing nature of the lesson; connection of theory with life, with practical and professional orientation; connection of collective forms of work with group and individual work; organization of active cognitive activity of students; a combination of presentation by the teacher with independent work of students on the acquisition of new knowledge and skills; operational control by the teacher over the activities of students [3].

Requirements for the method of practical classes in a foreign language:

- the teaching methods and techniques should help to make the lesson emotional, arouse students ' interest;

- the pace and rhythm of the lesson should be optimal, the actions of the teacher and students completed;

- full contact between the teacher and students is necessary;

- creating an atmosphere of goodwill and active creative work in the classroom;

- combination of various methods and techniques that gives different types of student activities;

- during the lesson students must actively work on mastering theoretical knowledge and practical skills;

- the entire learning process in the classroom is managed by the teacher [3].

\section{Conclusion}

Many conditions are important for acquiring the professional qualities, and this process is individual. The main thing is the teacher's attitude to self - education, the desire to master their profession. The second condition is the ability to self - analyse and self-evaluate. The atmosphere at the University also matters - relationships with colleagues, the ability to attend their classes, as well as the presence of a methodological office at the Department.

In general, professional competence of a University teacher is a set of skills to structure scientific and practical knowledge for optimal solution of pedagogical and educational tasks. The professional competence of a University teacher is a synthesis of professionalism (scientific, special, methodological, psychological and pedagogical training), creativity (creativity of relationships, the optimal use of tools, techniques, teaching methods) and art (acting and public speaking). And today it becomes obvious that it is impossible to "add up" a competent professional from a simple sum of knowledge, because in addition, a University teacher should have a great sense of moral responsibility when teaching the modern generation of students [4]. 


\section{References}

1. B. S. Gershunsky, Philosophy of education for the XXI century (in search of practiceoriented educational concepts) (Sovershenstvo, Moscow, 1998)

2. I. I. Burlakova, On some forms of methodological support for teachers, J. Innovations in education, 8, 5-11 (2015)

3. I. I. Burlakova, Main aspects of educational work in the higher education system, J. Orthodox scientist in the modern world, 2, 127-132 (2016)

4. N. V. Volkova, Technology of designing educational events, J. Education and science, 4, 184-200 (2017).

5. M. N. Vetchinova, Theory and practice of foreign language education in Russian pedagogy of the second half of the XIX - beginning of the XX century (Moscow, 2009)

6. N. D. Halskova, N. Gez, Theory of foreign language teaching: linguodidactics and methodology (Academy, Moscow, 2006)

7. D. Dze, I. I. Burlakova, Formation of communicative competence in students using the group form of classroom work, J. Russian language abroad, 4 (275), 113-119 (2019)

8. V. Y. Laudis, Methods of teaching psychology (URAO publishing, Moscow, 2000)

9. O. A. Pavlova, N. I. Chirkova, Professionally oriented projects of pedagogical orientation as a tool for stimulating professional self-development of future teachers, J. Education in Nizhny Novgorod, 1 (2020)

10. E. I. Passov, Program-concept of communicative foreign language education (Moscow, 2000)

11. Yu. V. Proshunina, Psychological features of professional communication, J. Bulletin of the Russian University, 10, 33-40 (2006).

12. E. B. Gök, Changing Educational Paradigms: New Methods, Directions, and Policies (Berlin, 2020)

13. Z. Wang, Application of the Mobile Terminals in the Long-Distance Continuing Education for Preschool Teachers, J. 2020 Advances in Intelligent Systems and Computing, 1017, 1027-1033 (2020)

14. I.A. Greshilova, S.Z. Kimova, B.B. Dambaeva, Designing the model of professional development of teachers taking into account axiological imperatives of continuing education, J. Universal Journal of Educational Research, 8 (3), 769-778 (2020)

15. B. Gospodinov, R. Peytcheva-Forsyth, B. Mizova, Bulgarian Teacher Preparation and Continuous Professional Development-Problems and Perspectives for Change, J. Teacher Education in the Global Era: Perspectives and Practices, 49-63 (2020)

16. C. Foster, M. Inglis, Mathematics Teacher Professional Journals: What Topics Appear and How Has This Changed over Time?, J. Intonal Journal of Science and Mathematics Education, 17 (8), 627-1648 (2019)

17. D.Tosh, B. Werdmuller, Creation of a learning landscape: weblogging and social networking in the context of e-portfolios, retrieved from https://docplayer.net/7520363- 
Creation-of-a-learning-landscape-weblogging-and-social-networking-in-the-contextof-e-portfolios.html

18. Y Huang, G. Huang, Design and implementation of web-based teacher remote training platform, J. Materials Science and Engineering, 750 (1), 609-615 (2020)

19. C. Urbani, Teacher continuing professional development and team-working competences: A case study from Italy, J. International Journal for Research in Vocational Education and Training, 7 (2), 237-255 (2020)

20. K. Stenberg, K. Maaranen, The differences between beginning and advanced student teachers' teacher identities based on their practical theories, J. Education Inquiry, 11 (3), 196-210 (2020) 